\title{
Analysis of the motivational features of the choice of the teaching profession by students
}

\author{
Natalia Polkovnikova ${ }^{1 *}$ \\ ${ }^{1}$ Moscow City University, Institute of Pedagogy and Psychology of Education, Moscow, Russia
}

\begin{abstract}
The relevance of the present study is determined by the demand of the state and society for training pedagogical personnel who are highly motivated for professional activity and chose their profession consciously. Thus, the first premise of the conducted study lies in the need to improve the quality of pedagogical training in the Moscow metropolis. The second premise is the need for the scientific study of the structure of personality and the interrelation of its components presented by personal values and the motives behind the choice of profession. The study aims to identify the correlation of personal value orientations and motives for choosing a future profession in students of the pedagogical faculty of the Moscow City University. The study methods include projective methods (a survey and essays) and standardized methods (Rokeach's Personal Values Survey, Schwartz's Value Survey, and "Test of life-meaning orientations" by D.A. Leontiev). The study confirms that personal values correlate with the motives for the choice of profession in pedagogical faculty students. A high correlation between the motive behind choosing the teaching profession and personal values is found in the orientation on interaction with people and on oneself, awareness of one's professional choice, and social and cultural conditioning. In the categories of gender and financial status, the motives for choosing a profession do not correlate with students' personal values. The novelty of the study lies in the identification and empirical verification of the scientific method for determining students' involvement in the future teaching profession. The significance of the study is found in the fact that it reveals a new technology for vocational guidance of applicants of pedagogical university training programs. Moreover, implementation of the study results may increase the effectiveness of the design of students' education in improving their professional motivation. The presented research makes a scientific contribution to the study of a person's activity and independence in selfrealization in life, the freedom of choice and responsibility for it, for one's decisions and actions, as well as in the study of the values of future teachers.
\end{abstract}

Keywords: choice of profession, personal values, education of students, pedagogical training.

\footnotetext{
${ }^{*}$ Corresponding author: polkovnikovanb@mgpu.ru
} 


\section{Introduction}

Interest in the problem of personality formation has been present in psychology for several recent decades. The problem of personal and social values is covered by psychological science in the interpretation of orientation as the leading characteristic of personality. This idea is developed by the leading Russian scientists B.G. Ananiev [1], A.N. Leontiev [2], S.L. Rubinshtein [3], and others through various methodological approaches (Fig. 1).

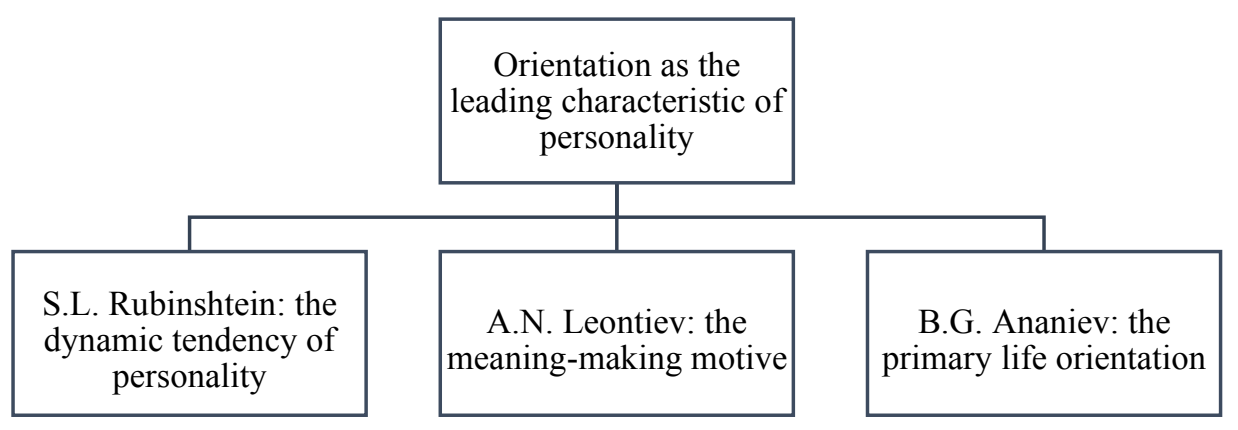

Fig. 1. Values and motives in the orientation of the personality.

In modern days, the attention of researchers is focused on the sphere of education and the professional pedagogical community. Their scientific interests are determined by the search for the mechanisms and ways of designing effective educational programs and technologies and training teachers for different levels of education. Studies of the following authors are conducted within this framework: A.R. Fonarev [4]; D.I. Feldshtein [5]; N.B. Polkovnikova [6]; A.G. Asmolov [7]; I.M. Remorenko, B.D. Elkonin, K.A. Barannikov, E.V. Chudinova, P.G. Nezhnov et al. [8]; V.S. Sobkin, A.I. Andreeva, and F.R. Rzaeva [9]; B.M. Bim-Bad [10]; V.I. Slobodchikov [11]; D.A. Leontiev [12]; V.A. Ivannikov, A.N. Gusev, and D.D. Barabanov [13]; A.I. Podolskii and O.A. Idobaeva [14]; I.V. Vachkov, S.N. Vachkova, and M.V. Voropaev [15]; K.A. Barannikov, S.M. Lesin, S.N. Vachkova, R.S. Suleimanov, and R.B. Kupriyanov [16]; G. Ferreira, M. Gastal, and M. Avanzi [17]; M. Ferrero, E. Konstantinidis, and M. Vadillo [18]; O.V. Maslova, D.A. Shlyakhta, and M.S. Yanitskiy [19]; J. Moate and M. Ruohotie-Lyhty [20]; A. Stellmacher, S. Ohlemann, J. Pfetsch, and A. Ittel [21]; J. Underwood, M. Kowalczuk-Walędziak, and J. Palmer [22].

Analysis of the current state of the study of the indicated problem allows us to state that the acute issue of the relationship between values and motives in choosing a profession in the structure of a teacher's personality requires further research.

The study hypothesis proposes that there is a correlation between the value orientations of personality and the motivation for the choice of the teaching profession.

The goal of the study is to examine the correlation between the value orientations of personality and the motives for choosing a future profession in students of a pedagogical faculty.

The study objectives include the analysis of theoretical approaches to the study of the connections between the personal values of a subject and their motivation, studying the motives behind the choice of a profession and personal values in pedagogical university students, and identifying the correlation between personal values and the motives for choosing a profession. 


\section{Methods}

The study methods include projective methods (a survey and essays) and standardized methods (Rokeach's Personal Values Survey [23], Schwartz's Value Survey [24], and "Test of life-meaning orientations" by D.A. Leontiev [12]).

The study sample includes 46 first-year students (female) of the pedagogical direction of training at the age of 17-19 years old. The empirical stage of the study was conducted in 2019 at the Moscow City University.

\section{Results}

Analysis of the results of the survey and the content of essays allows to determine the criteria and indicators of motives for choosing a profession in students of the pedagogical direction of study:

- the criterion of orientation on interaction (indicators: love for children, desire to help, desire to work with children, interest in children),

- the criterion of orientation on oneself (indicators: the desire for self-development, self-realization, the opportunity to study what is interesting, creative self-realization, demonstration of one's creative abilities, professional success, the desire to understand oneself, infantilism, for instance, the desire to be a child, return into childhood, spend time with children),

- the criterion of the awareness in the choice of a profession (indicators: interest in the work of a teacher, knowledge of the teaching profession, understanding the requirements for a teacher and one's compliance with them, the randomness of a professional choice or a choosing under the influence of external circumstances, for example, the Unified State Exam results, the university being located close to one's home, or applying together with a friend),

- the social criterion (indicators: continuing a dynasty of teachers, following the example of an authoritative adult or the advice of loved ones),

- the cultural criterion (indicators: being inspired after reading a book about teachers, watching a film about teachers, or being under the influence of pedagogical sites on the Internet),

- the gender criterion (indicators: the profession of a teacher is typically "female" and professional knowledge can be helpful in life, that is, in creating a prosperous family and raising children),

- the financial criterion (indicators: the salary of a teacher is adequate to the required efforts and good working conditions, teachers have a paid short working day, paid sick days, large paid leave).

Based on the survey results, the most common answers to the question "Why did I choose the teaching profession?" included: love for children, interest in the profession of a teacher, the desire to help others, orientation on interaction with adults and children, selfdevelopment and self-realization, and the need to understand oneself and other people. Thus, we identified the declared motives of the professional choice of the respondents.

The second stage of the empirical study included questionnaires by Rokeach, Schwartz, and D.A. Leontiev. The obtained results were entered into the same table as the results of the survey. The combined study results were then cross-tabulated using Spearman's correlation coefficient in the IBM SPSS software. The obtained numerical values of the coefficient of correlation between the indicators reflecting the motives of professional choice and the value orientations of an individual were divided into three levels: the high level - values of 0.5 and higher; the average level - values from 0.3 to 0.5 ; the low level - 
values from 0.2 to 0.3 . Correlation coefficients below 0.2 were not taken into account in the analysis of the results.

High coefficients of correlation between personal values and motives for choosing a profession were obtained in the indicators presented in Figure 2.

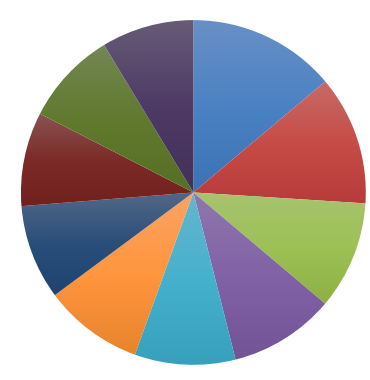

development, self-improvement (Rokich's method) - interest in the profession

- personality maturity (Schwartz's method) - interest in the profession

- love (Rokich's method) - love for children

intolerance of shortcomings (Rokich's method) - the desire to work with people

v creativity (Rokich's method) - interest in the profession

- enjoying life (Schwartz's method) - the desire to dive back into childhood

- social status (Rokich's method) - the choice of profession under the influence of a book

- purpose in life (D.A. Leontiev's method) - knowledge about the work of a teacher

- locus of control in life (D.A. Leontiev's method) - awareness of the requirements for a teacher

maturity, personal autonomy (Schwartz's method) - the desire to understand oneself and others

Fig. 2. High correlations between personal values and motives for choosing a profession in students of the pedagogical direction of study.

\section{Discussion}

In Figure 2, the highest correlation coefficient (0.803) is evidence of the value of development, work on oneself, self-improvement, and interest in the profession or professional activity being a significant personal motive. Interest in the profession as a motive for choosing a profession correlates with the value of maturity and autonomy and the recognition of one's individuality with a correlation coefficient of 0.704 . The value of "love" (Rokeach's method) correlates with the choice of a profession conditioned by love for children with a correlation coefficient of 0.588 . The correlation between the intolerance of one's own and others' shortcomings and the desire to work with children showed a value of 0.574 . The interrelation of the categories of interest in the profession and creativity with a correlation coefficient of 0.547 reveals the essence of the teaching profession which can be viewed as an art.

The result of the correlation between the categories of "enjoying life" and "the desire to dive back into childhood" (correlation coefficient of 0.541 ) draws some interest. Childhood 
is a happy, carefree period of life, a time of enjoyment and pleasures. The idea that young people see the chosen profession as an opportunity to extend their childhood and return to this carefree time is supported by the examples from questionnaires and essays: "I expect my profession to bring me back to my abandoned childhood"; "I chose the teaching profession because I like being a child myself". The desire to return to childhood, to become a child once again can be interpreted as an infantile tendency.

The correlation coefficient of 0.515 between the category of social status (Schwartz's method) and the choice of the profession under the influence of a book is associated with the fact that the majority of respondents mentioned the book "Hello, Children!" by Sh. A. Amonashvili in their answers. The figure of a talented teacher plays a significant role in the indicated book.

The discovered correlation between the categories of goals in life operationalized through D. A. Leontiev's method of life meaning orientations and the objectivity of ideas about the essence and content of professional activity (correlation coefficient of 0.511 ) can be explained by the meaningfulness of professional choice as a significant part of life, a vision of oneself in the future.

The interrelation of the categories of the locus of control and the manageability of life according to D. A. Leontiev's method and the understanding of the requirements posed for a teacher with the correlation coefficient of 0.509 demonstrates the same component of awareness as the latter case as demonstrated in essays: "A teacher is a difficult profession because it presents a great responsibility to children and parents".

The possible interpretation of the correlation between the categories of maturity, autonomy, and recognition of one's own individuality and the motive "to understand oneself" and other people (correlation coefficient of 0.502 ) is quite obvious. The personality develops while passing through certain stages of life, for example, professional self-determination.

Let us move on to discussing the mean values of the correlation coefficient. The most "loaded" mean values are found in the indicators of the criterion of orientation towards interaction with others. According to the criterion of orientation on oneself, the highest values of mean correlation coefficients were discovered in the indicators of striving for selfdevelopment, self-realization, creativity, and infantilism.

A low but significant correlation (0.2-0.3) between personal values and motives for choosing a profession is interpreted by us as non-accidental. Correlation with a low coefficient is observed in the value scales of love, having friends, the happiness of others, tolerance, responsibility and strong will, and conformism.

The criteria least "loaded" with significant correlation coefficients are gender and financial status.

\section{Conclusion}

The conducted study allowed us to explore the motivational sphere of the personality of students of the pedagogical direction of study. The obtained results supported the assumption that personal values determine the motives behind choosing the teaching profession. A correlation between personal values and motives for choosing a profession was revealed among students studying in the pedagogical direction of training. The values of the correlation coefficients demonstrate the degree of future teachers' involvement in professional activities and their self-identification with the profession. A high degree of correlation between motives for choosing a teaching profession and personal values is observed in the orientation on interacting with people, orientation on oneself, awareness, and social and cultural conditioning of professional choice. 
The investigated problem is one of many related to the study of a person's life path and involvement in various activities. Uncertainty presents a key characteristic of the modern world and human life. It requires adequate responses and concrete actions from an individual. The conducted study interprets the behavior of young people in the context of professional choice. The foundation of the study is formed by axiological knowledge in psychology. From our perspective, the deployed methods and the obtained results present new opportunities for the study of the subject position of a person in their own life, freedom of choice and awareness of one's responsibility for it, and the role of personal values in decision-making. The acquired results can be used in designing educational work and organizing vocational guidance work with future university applicants.

\section{References}

1. B.G. Ananiev, O problemakh sovremennogo chelovekoznaniia [On the problems of modern human science] (Piter, Saint Petersburg, 2001)

2. A.N. Leontiev, Deiatelnost. Soznanie. Lichnost [Activity, Consciousness, and Personality] (Politizdat, Moscow, 1975)

3. S.L. Rubinshtein, Chelovek i mir [A Man and a World] (Publishing house Piter, Saint Petersburg, 2012)

4. A.R. Fonarev, Voprosy psikhologii, 6, 54-62 (2004)

5. D.I. Feldshtein, Voprosy psikhologii, 1, 46-65 (2013)

6. N.B. Polkovnikova, L'association 1901 SEPIKE, 3, 41-44 (2013)

7. A.G. Asmolov, Narodnoe obrazovanie, 5, 48-52 (2008)

8. I.M. Remorenko, B.D. Elkonin, K.A. Barannikov, M.V. Klarin, E.V. Chudinova, V.A. Lvovskii, A.G. Asmolov, P.G. Nezhnov, et al., Deiatelnostnyi podkhod v obrazovanii. Kniga 1 [Activity approach in education. Book 1] (Non-profit partnership for the promotion of scientific and creative intelligentsia in the integration of world culture "Authors' Club", Moscow, 2018)

9. V.S. Sobkin, A.I. Andreeva, F.R. Rzaeva, Voprosy psikhologii, 2, 88-99 (2018)

10. B.M. Bim-Bad, Izvestiia Rossiskoi akademii obrazovaniia, 1(49), 56-64 (2019)

11. V.I. Slobodchikov, Profilaktika zavisimostei, 1(17), 1-3 (2019)

12. D.A. Leontiev, Obrazovatelnaia politika, 3(79), 10-16 (2019)

13. V.A. Ivannikov, A.N. Gusev, D.D. Barabanov, Moscow University Psychology Bulletin, 2, 27-44 (2019). https:// doi.org/10.11621/vsp.2019.02.27

14. A.I. Podolskii, O.A. Idobaeva, Voprosy psikhologii, 2, 45-58 (2019)

15. I.V. Vachkov, S.N. Vachkova, M.V. Voropaev, Psychological Science and Education 24(3), 19-31 (2019). https://doi.org/10.17759/pse.2019240302

16. K.A. Barannikov, S.M. Lesin, S.N. Vachkova, R.S. Suleimanov, R.B. Kupriyanov, Revista Inclusiones, 7(S3-3), 1-8 (2020)

17. G.L. Ferreira, M.L. Gastal, M.R. Avanzi, Olhares \& Trilhas, 22(2), 183-202 (2020). https://doi.org/10.14393/OT2020v22.n.2.55629

18. M. Ferrero, E. Konstantinidis, M.A. Vadillo, Frontiers in Psychology, 11, 577738 (2020). https://doi.org/10.3389/fpsyg.2020.577738

19. O.V. Maslova, D.A. Shlyakhta, M.S. Yanitskiy, Behavioral Sciences, 10(3), 66 (2020). https://doi.org/10.3390/bs10030066 
20. J. Moate, M. Ruohotie-Lyhty, Journal for the Psychology of Language Learning, 2(2), 92-106 (2020). http://www.jpll.org/index.php/journal/article/view/34/moate_lyhty

21. A. Stellmacher, S. Ohlemann, J. Pfetsch, A. Ittel, International Journal for Research in Vocational Education and Training, 7(2), 214-236 (2020). https://doi.org/10.13152/IJRVET.7.2.5

22. J. Underwood, M. Kowalczuk-Walędziak, J. Palmer, Kultura I edukacja, 2(128), 156173 (2020). https://doi.org/10.15804/kie.2020.02.09

23. M. Rokeach, The nature of human values (Free Press, New York, 1973)

24. S.H. Schwartz, Advances in Experimental Social Psychology, 25, 1-65 (1992). https://doi.org/10.1016/s0065-2601(08)60281-6 